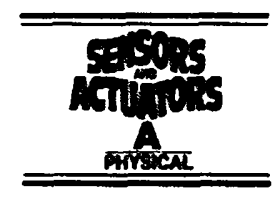

\title{
Microsystems technology: objectives
}

\author{
Jan Fluitman \\ MESA Reseurch Institute, University of Twente, PO Box 217. 7500 AE Enschede, Netherlands
}

\begin{abstract}
This contribution focuses on the objectives of microsystems technology (MST). The reason for this is two fold. First of all, it should explain what MST actually is. This question is often posed and a simple answer is lacking, as a consequence of the diversity of subjects that are perceived as MST. The second reason is that a map of the somewhat chaotic field of MST is needed to identify sub-lerritories, for which standardization in terms of system modules an...nterconnections is feasible. To define the objectives a pragmatic approach has been foilowed. From the literature a selection of topics has been chosen and collected that are perceived as belonging to the field of MST by a large community of workers in the field (more than 250 references). In this way an overview has been created with 'applications' and 'generic issites' as the main characteristics.
\end{abstract}

Keywords: Microsystems technology

\section{Introduction}

This contribution focuses on the objectives of microsystems technology (MST). The reason for this is two fold. First of all, it should explain what MST actually is. This question is often posed and a simple answer is lacking, as a consequence of the diversity of subjects that are perceived as MST. The second reason is that a map of the somewhat chaotic field of MST is needed to identify sub-territories, for which standardization in terms of system modules and interconnections is feasible.

\section{A short history of microsystems technology (MST)}

The roots of MST lie in the early 1980s when a number of activities gave birth to this working field explicitly. Of course 'roots' develop only in a fertile soil and we can go back to the times when the soil was fertilized by a number of ingredients: the microprocessor concept, solid-state sensors and actuators, optical waveguide technologies, bulk and surface micromachining, etc. A broad awareness of the promises of systems in microtechnology, however, had to wait for the early 1980s (although a real microsystem like the silicon micromachined gas chromatograph had already been developed in the 1970s).

This contribution is dedicated to Simon Middelhoek, one of the great pioneers cultivating the soil, particularly with silicon sensors [1], in which MST grows and shows her romise.

\subsection{USA}

Based on existing know-how concerning silicon micromachining and the prospects of the micro actuator, in the USA the IEEE Micro Robots and Teleoperators Workshop was held in 1987 and after that the landmarking report of the Workshop on Microelectromechanical Systems Research appeared under the title: 'Small machines, large opportunities: a report on the emerging field of microdynamics' [2]. Original copies of this icport might become collector's items. These activities led to the regular MEMS Workshops and . Pfter that to the IEEE/ASME Joumal of Micro Electro Mechanical Systems.

The symbols of MEMS-USA are the electrostatic linear and rotating micromotors (rotating around UC Berkeley), devices with free-ı unning parts completely etched free from the substrate.

\subsection{Europe}

From Europe the invention of the scanning tunnelling and the atomic force microscope inspired many activities, as did the LIGA technology, a spin-off development from nuclear physics research. The first formal activity in MST was the start of the Micro Mechanics Europe Workshop in Twente in 1989, followed by the first MST Workshop in Berlin in 1990. 
After that, many workshops and meetings were held all over Europe, showing the need for 'The United States of Europe'. although the foundation of the ESPRIT network NEXUS in 1992 has led to a converging trend in the Eurcpean activities. In the 4th Framework Programme of the EC, MST has finally got its own chapter [3].

\subsection{Japan}

In Japan the global trends of the mainly silicon-based developments in the USA were followed at universities (Tokyo, Sendai) and easily integrated in the more liberal context of miniaturization and precision engineering. MST in Japan has a pronounced 'mechanical' background. More than in other countries, the Japanese activities were characterized by an open approach concerning materials, technologies, industrial cultures, etc. In 1988 the Micro Machine Research Society was founded and in 1991 the MITI-supported R\&D project in MST started, with the Micromachine Centre as a supporting organization [4]. The word 'micromachine' (a miniaturized machine) scems characteristic of the Japanese perception.

Of course, this short history of MST is grossly incomplete. We shall not work out the details. We simply conclude that in a very fruitful environment, in some period in the early 1980s MST was born, and the world jumped onto it.

\section{Perception of MST}

MST stands for microsystems technology. The term 'micro' is used in its meaning 'opposite to macro' and does not refer to 'micron' or 'micrometre'.

'Micro' in 'microsystems technology' is used as in 'microscope', a device to look at small things. How small does not matter. A standard optical microscope goes down to the optical wavelength limit. But a scanning near-field optical microscope (SNOM) or an atomic force microscope (AFM) goes down to the nanumetre range and beyond. Nevertheless, they are ..! called microscopes. So, in our approach we include issues related to nanotechnology, which is also a term used to specify a certain area of activities in the field of MST.

Historically 'micro' refers to 'hardly or not visible with the bare eye', i.e., all beyond, say, $0.1 \mathrm{~mm}$ or $100 \mu \mathrm{m}$. This is a good tongue in cheek definition, which should be used in a lenient way. In a recent report [5] a measure of $10 \mu \mathrm{m}$ is suggested.

It is difficult to imagine practical questions in which such a measure will be really conclusive.

To define MST properly, and to omit issues of minor importance, our approach is: (a) to find out how MST is perceived up to now; (b) to find out for what purposes a definition is desired.

To start with the latter, a definition is desirable for proper communication. There are many terms that are used in the literature in a rather ambiguous way. Mostly these are terms that are used within the field of MST, such as bulk and surface micromachining, micromechanics, micromotors, microrobots, micromanipulation, etc.; and somewhat deeper, aspect ratio, sticking, closure of valves, etc. In fact a proper definition of such terms is more urgent than the proper definition of MST. A proposal for the standardization of terminology is being worked out at the Micromachine Centre in Japan, while first proposals concerning standardization have appeared at the moment of writing this text [5]. As we shall see, the maturing of certain areas in MST into industrial activities depends on the success of proper specification, normalization and metrology. So, in a sense the meaning of MST sholid be derived from definitions of these more specific terms. That is the way we go for the present: we shall dig into the more specific levels and return to the level of generalities afterwards.

Practical situations where a general definition is needed are non-technical in character, e.g., in the definition of programs to be subsidized, or in the selection of papers for, say, the MEMS Workshop or the MST Workshop. Occasionally the question arises: Is this really MEMS or MST? One might wonder if such practical situations are of enough importance to bother abcut the meaning of MEMS or MST? We think they are, as we shall explain at the end of this section.

Anyway, up to now common sense solved most problems of this kind, which means that some inherent perception of MST has grown in the minds of those participating in the discussion. Therefore it is interesting to analyse these perceptions. They strongly depend on the working fields, but what is shared is the fact that ihey all refer to the impression: This is a real new approach :o miniaturization, or to increasing the functional density; a real new approach to solving problems in the micro field; a real new function that can be implemented thanks to micro technology. And so on.

Characteristic examples are given below (a mixture oriented towards applications, technologies, principles, etc.).

\subsection{MEMS (microelectromechanical systems)}

In MEMS, as suggested in the USA report mentioned in Section 2.1. (surface) micromachined accelerometers (like the one proposed by Analog Devices [6] ), comb drive systems [7], gyroscopes, projection displays (like the one proposed by Texas Instruments [8]), micromotors, etc., are considered without hesitation as characteristic for MST. The technology and the typical dimensions are related to IC technology and there are free moving parts. That is the news (see Fig. 1).

\subsection{Cell biology}

From the point of view of the foregoing example (MEMS, with moving parts), one can wonder if there are any static devices perceived as MST devices. There are! For instance, microprobes to sense or stimulate nerves (Fig. 2) [9] are seen as objects of MST, as are micromachined filters to sep- 


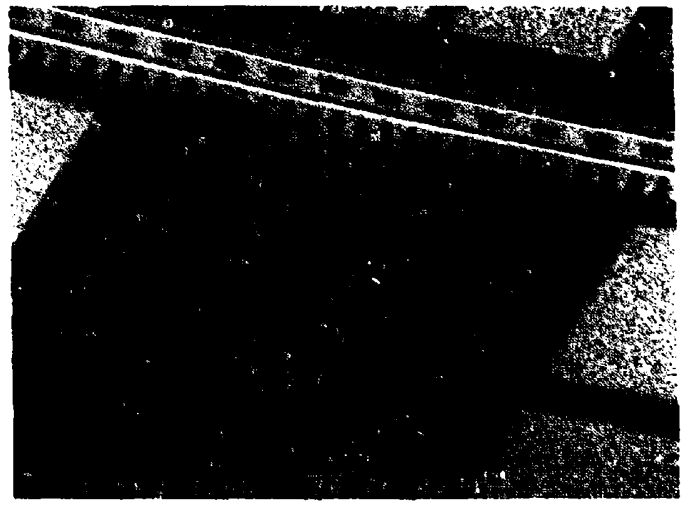

Fig. 1. Characteristic example of an original MEMS-type device. A polysilicon structure, in this case an electrostatic lower stator wobtle motor, is etclied free from the ground plane by removing a sacrificial layer. The axis of the motor is underneath and has the form of an upside down pin head kept in position by a matched cavity in the ground plane. This structure uransforms a rotation into a linear moventent (courtesy of Dr Rob Legtenberg. University of Twente).

arate cells [10] and micro punchers for DNA injection in cells [11]. In these cases the really new thing is that micro technology gives acisess to the micro world of biology. Here micro is pciceived in connection with the typical dimensions of advanced bioresearch: the cell and its parts.

\subsection{Micro surgery}

In micro surgery things are different again. An example is minimum invasive surgery based on the expanding art of catheter-tip manipulation. A catheter tip and the means for catheter-tip manipulation are in the (sub) millimetre range. Reliability in aggressive environments, often with slurries, and the need for force or power in the case of micro surgery are important. The characteristic dimensions are those in the field of precision engineering on which current devices are based. Here MST comes in with everything that may give added value or new functionality to the existing pioducts. Precision engineering meets MST in this field.

\subsection{Precision engineering}

By precision engineering we mean the classical field, developed as a part of mechanical engineering, and in existence for a long time. The field is evolving and leads to marvels, which are often unknown to MST engineers, with a background in electrical engineering and which are strongly biased by IC technology. Integration of MST and precision engineering is of great importance. Here we find a new characteristic: the meeting of disciplines. Or even: the meeting of cultures in technology (Fig. 3).

\subsection{Exploitation of effects of downscaling}

Downscaling of geometry may shift the relative usefulness of physical properties. On the level of phenomenological physics this has been emphasized by Trimmer [12], e.g., leading to the conclusion that for small micromotors electrostatic drive is favourabie to magnetic drive. Another example is in chemical sensors/actuators with respect to diffusicn effects and scale $[13,14]$.

On a still smaller scale short-range binding forces become manifest and can play an importanc role.

\subsection{Nancscale manipulation}

At the smallest end of the MST sp:ctrum we find the world of DNA manipulation, molecular self assembly $[15,16]$,
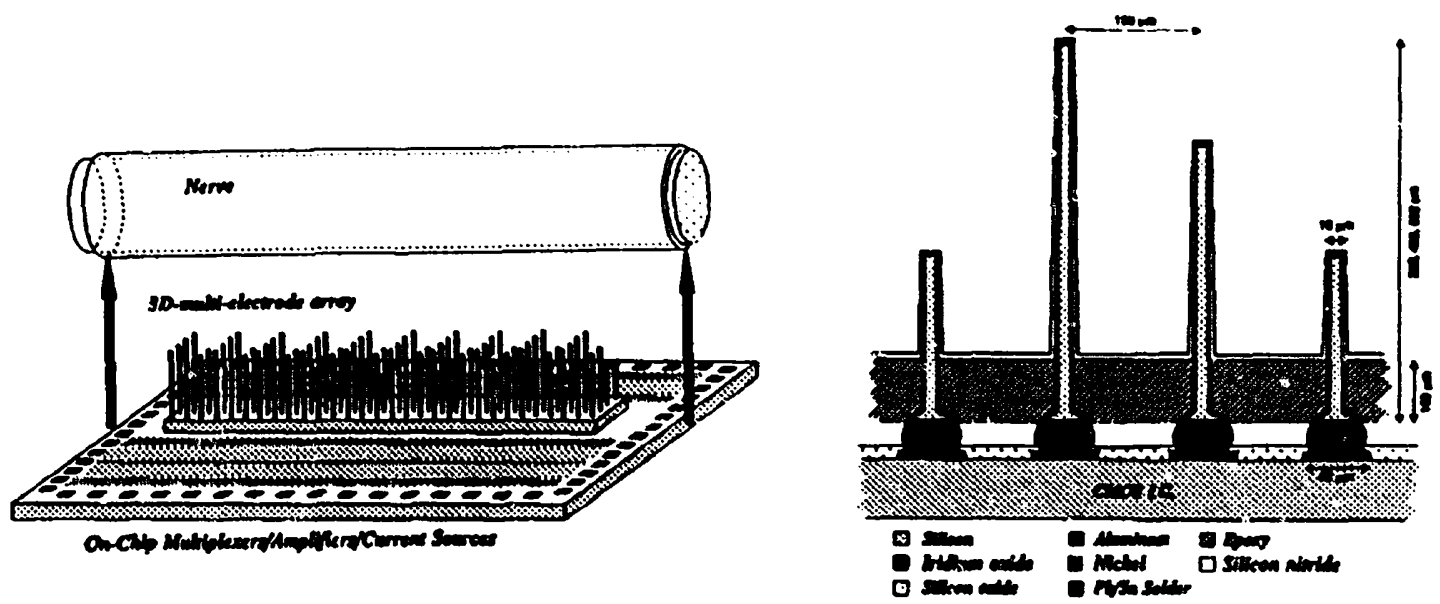

Fig. 2. Micromachined multi-electrode array ficr use in intrafascicular nerve stimulation. Lorit, tixe device as a whole; right, a close up showing the solder bump interface between the stimulator and a CMOS chip carrying multiplexers, current ssurces ano buffer amplifiers. This hybrid approach (be it virtually monolithic) points to an important development in designing microsystems. Note that the multi-electrode is three dimensional (courtesy of Dr Wim Rutitn, University of Twente). 


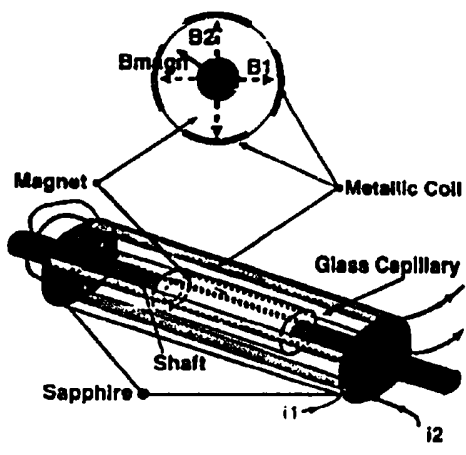

Micromotor

Fig. 3. Magnetic synchronous motor with a diameter of $1 \mathrm{~mm}$. Use is made of conventional sapphire bearings and the device can be seen as the result of conventional precision engineering. Nevertheless, there is a notion of the mecting of disciplines as mentioned in the text. Best results are obtained by considering all options offered by modern technologies (courtesy of Philips Research Laboratories).

laser microchemistry [ 17], etc., a world in which by artificial means individual structures in the nanometre range are handled or where self-organizing properties of aggregates are exploited in a controlled way. Here the characteristic dimensinns are derived from hig molecules like DNA or even proteins. This world is perceived as belonging to MST because the chemicals are not treated in bulk reactions alone, but are manipulated almost individually or controlled in a determined way.

\subsection{Miniuturization}

To sweep back to the bigzest end of the spectrum of MST, if one follows the development in, c.g., camcorder design, it can be seen that the art of hybridization is blooming. Here we live in the (sub)-millimetre range, with devices crammed on multilayer boards, exploiting sophisticated bonding and connection technologies and using advanced automatic production. Also this field is connected to MST by the experts who are working in it, and they are right because the spin-off of these technologies (interconnection, bonding, packaging, mounting, etc.) will go through the whole field of MST. Here miniaturization is the driver: a camcorder or a hard-disk drive in the palm of your hand (Fig. 4). Miniaturization of functions related to information technology is almost a law of nature [18].

\subsection{High-aspect-ratio technologies (HARTs)}

Almost right from the start the traditional LIGA technology [19] has been considered as a typical MST. Why?

IC technologists as well as precision engineers recognize the well-known art of lithography, with some exclusive features attractive for both parties. Tie first party appreciates the deep-etching possibility and the possible extension of their designs to three-dimensionai structures. The precision engi-

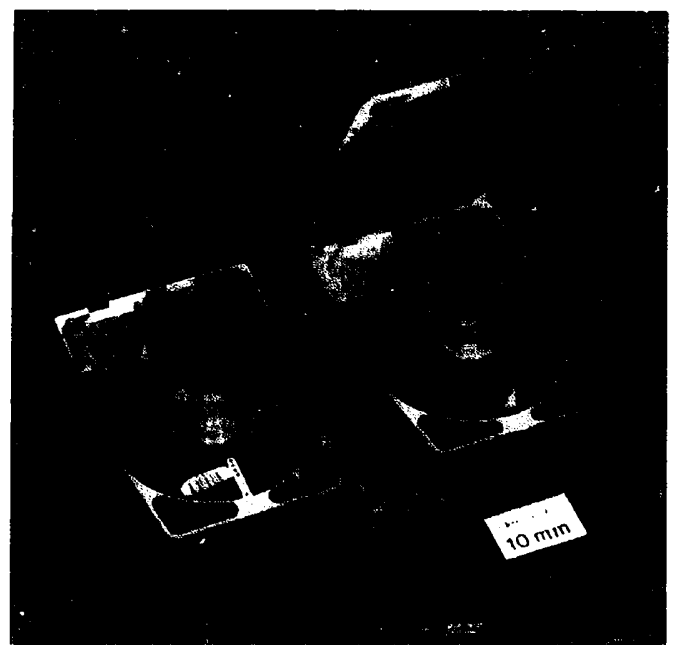

Fig. 4. Miniaturization in information technology is almost a law of nature. The increase of information density in space and time is an ongoing process in all aspects of information technology. The matchbox-sized hard-disk drive shown here has shrunk from its frigidaire-sized predecessor within a reriod of 25 years (courtesy of Mosaic of Plilips Research).

neers appreciate the high aspect ratio ind the typical dimensions of LIGA: right in their own working field. Anyway, LIGA might have played a historical rolc in bringing these parties together. In the mean time, LIGA has provoked intensive research in alternative HARTs like reactive ion etching [20] (Fig. 5) and laser ablation.

We could continue with such examples and outsiders might get the idea that MST is just a basket full of new things that are glamorous because of their smallness and often inherent beauty. They may conclude that in the end it is better to keep things apart and give up the aspirations of an MST as a whole.

Such a conclusion would be disastrous, however. The value of MST is in the meeting of disciplines (which is not only valid for MST). Therefore it is urgent to define MST by means of a collection of characteristic examples, on the one hand, but on the other hand by an identification of the results of the multidisciplinary approach and the characteristics thereof.

A conclusion based on this is that there is a need for conferences, journals and other means of communication that keep these things together. That is why it is important to tother about the meaning of MST in selecting papers for an MST workshop.

On the other hand, the list above points to a clear problem. We can agree to keep things together for the benefit of the inventors. But inventions must lead to products and the producers want to know how to find the way in this impressive wood of possibilities, where the price of pathways to interesting trees is unknown and probably high as well. So from their point of view order is desired and we therefore have to develop such an order ano see how we can define means for producers to arrive at the right actions. 

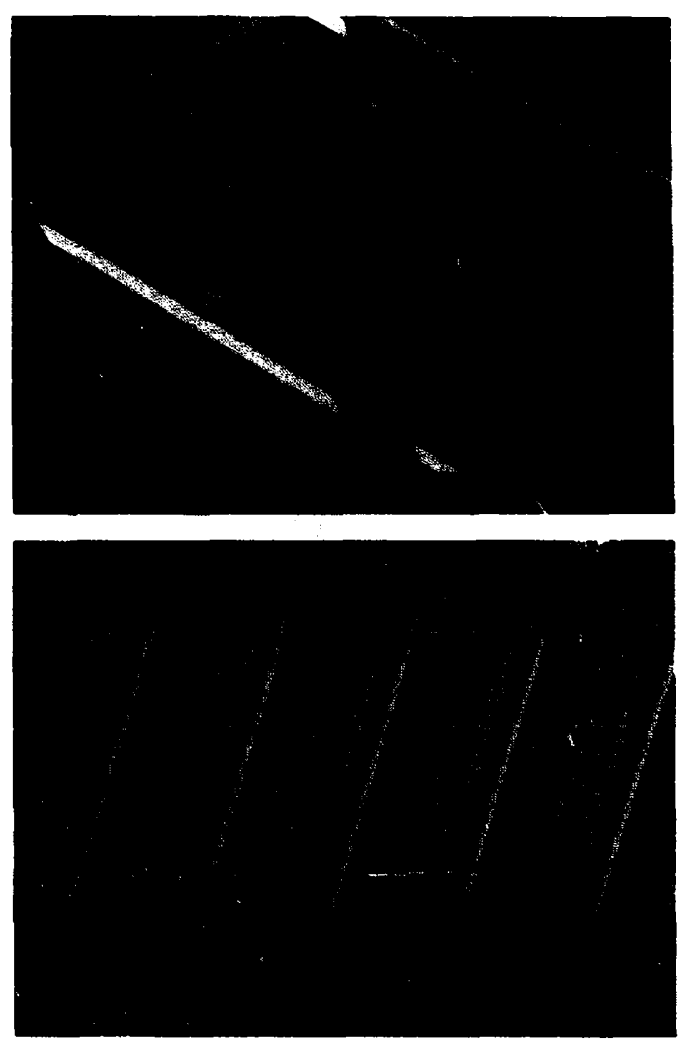

Fig. 5. Well-tuned reactive ion etching may lead to well-defined deep-etched structures with aspect ratios beiween 10 and 100 as is shown in the upper photoymaph. The long deep channel etched in silicon can be used in a micro chemical analysis systems. Very promising is the combination of reactive ion etching and techniques to release the structure from the ground plane. as is shown for the comb drive system in the lower photograph (courtesy of Dr Henry Jansen. University of Twente.)

\section{The quest for standards}

What detines MST is not so much determined by the characteristic feature sizes of less than 10 or $100 \mu \mathrm{m}$, but by the new production methods that bring such feature sizes, with all the promises of new functions and functional densities, within the range of possible and cost-effective production. These production methods have their roots in the lithographic techniques from precision engineering and above all, from IC technology. Mainly from the latter comes the possibility of integrated or batchwise production, leading to well-defined functions, processed in a parallel or wafer-scale mode. Waferscale production can be much cheaper than piecewise production, depending on the investments in technical facilitics, development costs and the production volume.

Two important remarks must be made here:

(1) The proposition that chip-level manipulation cannot compete with wafer-scale manipulation is not true in general. It is only valid for complex structures and feature sizes in the (sub) micron region. This can simply be checked by inspec- tion of an IC line. At the end of the line there are testers, scribers, bonders and pick and place machines to position and package the chips. These automates work on chip scale and not on wafer scale and they do not destroy the low process costs. Of course, the chip-manipulation machines have larger minimum feature sizes to handle than the wafer-scale machines. They start at the moment that the micro work is finished and the macro work starts. The feature size, which is characteristic for this turnover to individual manipulation, is roughly the size of the bond pad.

(2) Waferscale fabs in IC technology increase snarply in price as the feature sizes go down to the predicted $0.18 \mu \mathrm{m}$ level. In fact, the costs become so large that only some tens of fabs can survive, producing volumes that cover a worldwide demand [21].

Micro systems differ considerably from sophisticated ICs. They are generally much less complex and have larger feature sizes. The often stipulated analogy between ICs and micro systems is artificial to a large extent. Of course in historical perspective, MST can be seen as a logical extension of IC technology, but the differences are still so large that it is easy to arrive at the wrong conclusions when this analogy is taken too far.

Another point is the diversity of micro systems, as we shall see in Section 5. The generic factor in IC technology is much larger than in MST. Therefore it is much easier for IC technology to achieve standards for large-volume activities than it is for MST. ICs are much more variations on a theme than MiST products are.

For the evolution of MST this leads to two extremes:

(1) Either MST is forced to follow the trends of IC technology, which means that only those MST products survive that have the character of ICs as mentioned above. This will drastically reduce the promises of MST. (It is even difficult to huy commercial ICs in low-volume quantities from the big IC houses [22]).

(2) Or MST products are produced in a wide range, which means that the trend to follow the IC production technology must be left to a great extent and a lot of hybridization must be accepted. In fact hybrid technology can be seen as a part of MST itself (see Section 3.7). The development of IC technology to ever-larger wafers and ever-smaller feature sizes is not in the interest of MST at all. Small wafers, small machines and a modest IC facility are sufficient to produce MST novelties. Many people working in the field of MST are very unhappy with the thought that eventually they may be unable to buy small wafers.

The developments in bonding technology, e.g.. solder bump technology, might be a stimulus to think in terms of hybrids. (As a matter of fact, with such technologies the difference, between monolithic and hybrid becomes rather vague.) They might be of great help in the diversification of production technology. unless the degree of sophistication of these technologies, when oriented towards high-volume multichip moduic production, again lifts it outside the cost range of medium-scale production. 
The conclusion is that the current technological context is not MST friendly at all. Despite all its promises it is difficult to plan for a production facility for medium-scale production. MST seems to be locked between the world of precision engineering that has reached its limits and the world of IC technology that is far too overdimensioned for MST.

A necessary condition to overcome this situation is to achieve standardization of MST products and MST production facilities. Of course standardization reduces the variety of possible products, but a coinpromise between variety and production volumes must be found and such a compromise must be different from that in the IC world. This conclusion is not new at all, but the difficulty is how to implement standardization in the chaotic world of MST. It is a topic that cannot be treated in general terms.

Therefore it is necessary to identify the most important sub-domains of MST and to identify communities of interested persons that are large enough to put some weight on the scale. Without that the quest for standardization is just a sigh without any effect.

So, we have to work out the topics that are perceived as belonging to MST topics and see how we can define the MST sub-domains and the standardization issues at stake. As an example of an outcome, we mention micro fluid-handling systems where first proposals have been made concerning standardization of modules [23].

\section{Specific applications and generic functions}

In order to get a clear overview of MST, we have to choose the main characteristics. After some efforts, we found that application and generic function are the best to work with.

The procedure is to start from an application and decompose the systems gradually into subsystems until we finally reach the basic micro parts. This gives rise to a tree-like structure. The finest branches are the basic micro parts.

After many trees, it can be seen that the finest branches may coincide. If this overlap is for a large number of applications, we can conclude that we have identified a generic function.

After finding the generic functions, we can turn around the procedure and start from the generic functions and look for applications. In a sense, trees are growing now from the other side. After some time the numbers of applications and generic functions saturate and the exercise is completed. A first result is presented below.

Of course a continuous effort will be needed to keep the data base up to date. The full pirture of these trees is very complicated. Therefore we first present the lists of applications and generic functions we found by following this method. Next we present a more detailed scheme with many references. However, even this scheme is a reduced representation of all that exists.

\subsection{Short list}

\section{A pplications}

A1. Portable workplace for information handling

A2. Portable workplace for materials handling

B. Personal tools, domotics and leisure

C. Portable or implantable diagnostic and therapeutic means

D. Hospital

E. Production

F. Transport

G. Safety, monitoring

H. Research

I. Characterization and analysis

J. Communication

\section{Generic issues}
A. Sensors
B. Actuators
C. Resonators
D. Switches
E. Valves
F. Filters
G. Array-type systems
H. MST production
I. Energy supply
J. Materials supply
K. Energy conversion
L. Microrobotics

Note: There is no correlation in the order of the columns.

\subsection{Extended'ist}

Reference is made to recent contributions in conference proceedings, journals, company brochures, etc. Yet, the list is incomplete (e.g., patent literature has not been covered) and must be updated svery now and then. Since we have restricted ourselves to recent literature, many core papers are most probably not in the list, but may easily be found by tracing them from the reference lists in the papers.

\section{Applications}

A1. Portable workplace for information handling (laptop. etc.)

Data storage (Dig.) Video recording $[24,25]$

Magnetic disk

Smart recording slider [26-29]

Micromotor/disk [30,31]

Optical recording [32,33]

Magneto optical recording [34]

Nanometre recording [35-37]

Displays Review [38]

Flat panel displays [ 39,40$]$

Cathode ray tubes [41] 

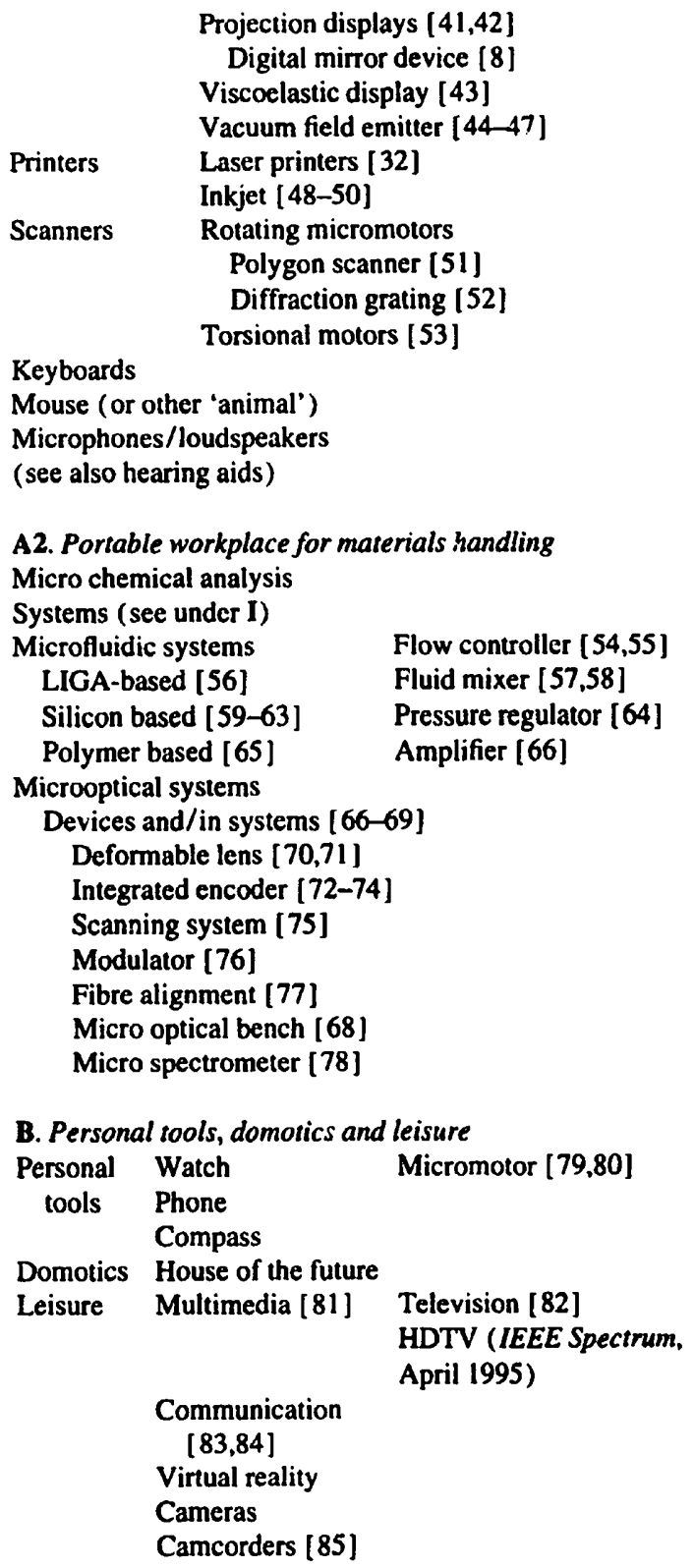

C. Portable or implantable diagnostic and therapeutic means

Body function monitoring Microdialysis [88-90] [86,87]

Drug delivery

Precision infusion [91]

Smart pills

Artificial sense organs [92]
Artificial body functions

Isiets of Langerhans [99]

Eye pressure controller [100]

Tonometer + telemetry [101]

Movement monitor [102]

Pacemaker, defibrillator

Neural interface

Channels [ 103, 104]

Channels + telemetry [ 105]

Prickers [106,9]

Electrodes [ 107]

Electrodes + telemetry [ 108]

Mechanical stimulation [109]

System connector [ 110 j

\section{Hospital}

Tele-operation

\section{Catheters}

Ultrasonic catheter [111]

Active catheter [112]

Tip assembly [113]

Minimal invasive

Minimal invasive heart surgery [92]

surgery

Minimal invasive eye surgery [114]

Catheter tip surgery [115]

Micromotors [116,117]

Power ultrasonics [118]

Tissue fastener [119]

Intensive care

monitoring

Imaging apparatuses

Therapeutic means

Tonometer [120]

Movement monitor [ 102]
E. Production

Process industry

Product industry

Farming [121]

Agriculture, horticulture [121]

MST production facilities

\section{MST test facilities \\ Production equipment}

Monitors moving with process

Engine, plant inspection (see G)

Pneumatic control (valves)

Paintjet

Micro stitching

Cattle monitoring

Crop monitoring (

Position (and fix)

(see also: arrays) [122]

Comb drive [123]

Vibromotor [124]

Scratch drive $[125,126]$

Nano lithography [ 127-129]

IC probe tester [130-132]

Micro assembly [133-136]

Micro manipulation [137-140]

Teleoperation [141]

HARTs

LIGA $[19,142]$

DEEMO [143]

Stereo lithography [144-146]

Surface finisining [ 147]

Conductive adhesives [148] 


\author{
Micro connection \\ Flip chip [149-151] \\ Multichip module [152] \\ Precision products Micro optics (see A) \\ Micro fluidics ( $\sec \mathbf{A}$;
}

\section{F. Transport}

Motorcars [153,154] Airbag inflation system [155]

Combustion control system [156]

Antilock braking system

Traction control system

Tyre performance system

Gyroscopes [ 157,158]

Fuel atomizer [159]

Driver monitoring [ 160]

Aeroplanes

Turbulence control $[161,162]$

Spacecraft [ 163]

Fluidic system [165]

\author{
Microreactors [ 186] \\ Chromatograph [ 187-189] \\ Injector \\ Thermal cond. device \\ Micro electrophoresıs [ 190,191$]$ \\ Enzyme reactors [192] \\ DNA analysis system [193-195] \\ DNA diagnostic array dispenser [196] \\ Micro mass spectrometer \\ Spectrometer \\ Yariable slit [197] \\ LIGA [78] \\ Micro atomic clock [ 198] \\ Micro probe STM $[199,129]$ \\ microscopy AFM $[200,35,36]$ \\ MFM [201] \\ SNOM [202] \\ Multiprobe [203] \\ J. Communication \\ Optical communication Switches [205] \\ [204] \\ Sensors [206] \\ Mechano-optical interface
}

\title{
Generic issues
}

$$
\text { elderly people }
$$

$\begin{array}{clc}\begin{array}{c}\text { Engine, plant } \\ \text { inspection }\end{array} & \begin{array}{l}\text { Mobile robots } \\ {[168]}\end{array} & \begin{array}{l}\text { Cameras [38] } \\ \text { OMRON Micro } \\ \text { Photonic device } \\ {[169,75]} \\ \text { Crack detector } \\ {[170,147]}\end{array} \\ & & \\ \text { Crop monitoring [121] } & \text { Air } & \\ \text { Environment } & \text { Surface water } & \text { Heavy metals detection } \\ & \text { Ground water } & {[171]}\end{array}$

H. Research

Micro probe techniques [172]

Cell manipulation [173]

$$
\begin{aligned}
& \text { Cell imaging [174] } \\
& \text { Grippers [175] } \\
& \text { Cell fusion [176] } \\
& \text { Cell separation [10,177] } \\
& \text { Cell cultivation [178] } \\
& \text { Cytometry [179] } \\
& \text { DNA manipulation } \\
& \text { Microchemistry [17] } \\
& \text { Probe tip manipulation } \\
& \quad[172]
\end{aligned}
$$

Nano manipulation

Nano synthesis [180]

\section{A. Sensors \\ In situ calibration [207-209] \\ Chemical sensors}

(see Chemical analysis systems, Applications I)

Proximity

Ultrasound [210]

Gyroscope $[157,158,211]$

Accelerometer [8] etc.

B. Actuators

Thermal

Electrostatic [212]

Electromagnetic

Electrochemical [213]

Pneumatic [60]

Thin-film SMA [214]

S-shape actuator $[215,216,167]$

C. Resonators

Resonator type sensors [2:7]

Fluid density sensor [218]

Optical scanner [75]

D. Switches

Relay [219-225]

Fluid flow switch [226]

Optical switch $[205,227]$

\section{Chemical analysis Chemical sensors [182,183]}

I. Characterization and analysis

systems [181] Sensors in microchemical analysis systems [184,185]

Microfluidic systems (

E. Valves

Fluids $[228,55,64,229,230]$

see also B: S-shape actuator) 
F. Filters

Cells $[177,10]$

Light [76]

Arificial muscles [231-234]

$[212,235,236]$

Odour sensors [237]

Positioning array [238-242,139]

Mirror arrays [8]

Vacuum emitter arrays [44]

Tactile sensors [137]

\section{H. MST production}

Tele operation

Micro manipulation

Particle handling [243]

Monolithic/hybrid
G. Array-type systems

\section{Conclusions}

We have made an overview of what can be considered as elements of microsystems technology using the characteristics application and generic issues. There are others, e.g., technology, or discipline in physics and/or chemistry. During our work we found out that the latter are much harder to use as a guideline for an overview.

With this overview the diversity of MST, as well as a Viscoelastic [43] possible order, is shown. This might be of help in getting a grip on the issue of standardization and preparation of MST for production.

The developments in IC technology to ever-larger wafers and ever-smaller feature sizes are not in the interest of MST. An MST production environment will be supported by the development of down-scaled equipment, while the trend is in scaling them up. Here is a chicken and egg problem: MST products and MST production facilities. Maybe this is at the heart of the problem of getting MST off the ground.

\section{Acknowledgements}

I would like io thank Albert Van den Berg, Piet Bergveld and Kees Eijkel for their valuable comments and suggestions to make the 'list' a little bit longer.

\section{References}

\section{J. Material supply}

Pumps [250-252,54]

\section{K. Energy conversion}

Micromotors Rotational [253]

Electric $[254,255]$

Magnetic [256,257]

Electric vs. magnetic [258]

Wobble motors [259-264]

Motor + gear [265]

Scanners [51,52]

Linear Vibromotor [124]

Scratch drive $[80,126]$

Comb drive [123]

Micro gear [265,266]

\section{Microrobotics}

Mobile robots [267]

Flying robots [268,269]

Wings [270]

Swimming [271]

\section{N. Trends}

Microelectronics [272,274]

Yield [273]

Conducting polymers [275]

Organic transistors [276]

Thin-film transistors
[1] S. Middelhoek and S.A. Audet, Silicon Sensors, Academic Press, New York, 1989.

(2) K. Gabriel, J. Jarvis and W. Trimmer (cds.), Small Machines Large Opporfunities: A Report on the Emerging Field of Microdynamics. AT\&T Bell Laboratories, 1987-1988, 31 pp.

[3] D. Beemaen and M. Wilkinson, Europractice, Microsystems in the 4h Framework Program, MST News. $1+$ (1995) 2-10.

[4] T. Hirano. Japanese activities in micromachining, MST News, 14 (1995) 14-17.

[5] PACT project team (H. Dorey. chaiman), Report on the microelectromechanics project, presented at PACT Meeting. Los Angeles, CA, USA. Feb. 1996.

16] F. Goudenough, Airbags boom when IC accelerometers see $50 \mathrm{G}$. Electronic Design. (August) (1991) 45-56.

[7] W.C. Tang. T.C. Nguyen and R.T. Howe, Laterally driven polysilicon resonant microstructures, Sensors and Acrwators. 20 (1989) 25-32.

[8] J.M. Younse, Mirrors on a chup. IEEE Spectrum, (Nov.) (1993) 2731

[9] W.L. Rutten, T.A. Frieswijk, J.P.A. Smit, T.H. Rozijn and J.H. Meijer, 3D neuro-electronic interface devices for neuromuscular control: design studies and realisation steps. Biosensors Bioelectron. 9 (1994) 1-13.

(10) C.J M. van Rijn and M.C. Elwenspoek, Micto filtration membrane sieve with silicon micromachining for industrial and biomedical applications, Proc. IEEE MEMS Workshop, Amsterdam. Netherlands, 1995, pp. 83-87. Hashmi. B. Brunert and M. Reed. Injection of DNA into plant and animal tissues with micromechanical piercing structures, Proc. IEEE MEMS Workshop, Amsterdam. Netherlands. 1995. pp. 111-115.
[11] W. Trimmer. P. Ling, C. Chin, P. Orton, R. Gaugler, S. Hashmi, G. 
[12] W.S.M. Trimmer, Micro robots and micromechnnical systems, Sensors and Actuators, 19 (1989) 267-287.

[13] W.E. Morf and N.F. de Rooij, Micro-adaptation of chemicial sensor materials, Sensors and Actuators A, SI (1995) 89-95.

[14] B. Van der Schoor, Coulometric sensors, integration of a chemical sensor-actuator system. Thesis. University of Twente. Enschede 1986.

[15] D.L Allara, Critical issues in application of self-assembled monolayers, Biosensors Bioelectron., 10 (1995) 771-783.

[16] A. Barraud, Engineering supramolecular artificial edifices designed fos a specific function, Biosensors Bioelectron., 9 (1994) 617-624.

[17] H. Masuhara, Manipulation, fabrication and spectroscopy in small domains, Proc. IEEE MEMS Workshop. Amsterdam. Netherlands. 1995, pp. 1-6.

[18] J.H.J. Fluitman, Micro systems technology, Proc. IEEE 1994 Custom Integrated Circuit Conference, San Diego. CA. USA. 1994, pp. 471478.

[19] W. Ehrfeld, P. Bley, F. Gớtz, P. Hagmann, A. Maner, J. Mohr, H.O. Moser, D. Munchmeyer, W. Schelb, D. Schmidi and E.W. Becker, Fabrication microstructures essing the LIGA process, Proc. IEEE Micro Robots and Teleoperators Workshop. Hyannis. MD. USA, 1987.

[20] H. Jansen, Plasma etching in microtechnology. Ph.D. Thesis. University of Twence. Enschede 1996.

[21] G.D. Hutcheson and J.D. Hutcheson, Technology and economics in the semiconductor industry. Scientific American, (January) (1996) $40-46$.

[22] G.H. Endress, Microelectronics: supreme way to success or gate to hell for the medium-sized industry, speech given at SICAN Hannover. Germany, 14 March, 1994.

[23] T.S.J. Lammerink, V.L. Spiering, M. Elwenspoek. J.H.J. Fluitman and A. van den Berg, Modular concept for fluid handling systems: a demonstrator micro analysis system, Proc. IEEE MEMS Workshop, San Diego. CA. USA, 1996, pp. 389-394.

(24] M. Umemoto, Y. Eto and T. Fukinuki, Digital video recording, Proc. IEEE. 83 (1995) 1044-1054.

[25] J. Hamalainen, Video recording goes digital, IEEE Spectrum, (April) (1995) 76-79.

[26] J.F. Burger, G-J. Burger. T.S.J. Lammerink. S. Imai and J.H.J. Fluitman. Miniaturised friction force measuring system for tribological research on magnetic storage devices. Proc. IEEE MEMS Workshop. San Diego. CA. USA. 1996. pp. 99-104.

[27) G.J. Burger, T.S.J. Lammerink, J.H.J. Fluitman, S. Imai, M. Tokuyama and S. Hirose, Piezoelectric impact force sensor array for tribological research on rigid disk media, Proc. IEEE MEMS Workshop. Amsierdam. Netherlands, 1995, pp. $294-299$.

[28] V. Temesvary, S. Wu, W.H. Hsich, Y. Tai and D.K. Miu, Design. fabrication and testing of silicon microgimbals for super-compact rigid disk drives. J. MEMS, 4 (1995) 18-27.

[29] T. Imamura, T. Koshikawa and $M$. Katayama, Transverse mode electrostatic microactuator for MEMS-based HDD slider. Proc. IEEE MEMS Workshop. San Diego, CA. USA, 1996, pp. 216-221.

[30] L.-S. Fan and S. Woodman. Batch fabrication of mechanical platforms for high density data storage. Tech. Digest, 8 th Int. Conf. Solid-State Sensors and Actuators/Eurosensors IX. Stockholm. Sweden, 1995. Vol. 1.pp. 434-437.

[31] N.J.Mourlas, K.C. Stark, M. Mehregany and S.M. Phillips, Exploring polysilicon micromotors for data storage micro disks, Proc. IEEE MEMS Workshop. San Diego. CA, USA, 1996. pp. 198-202.

[32] D.B. Carlin and Y. Tsur. Sts, Diste lisers for mass market applications: optical recording and printing, Proc. IEEE, 82 (1994) 469-481.

[33] P. Asthana, A long road to ovemight success, IEEE Spectrum, (Oct.) (1994) 60-66.

[34] M. Kaneko, K. Araani, A. Fukumoto and S. Miyaoka, IRISTER Magneto-optical Jisk for magnetically induced super resolution, Proc. IEEE, 82 (1994) 544-553.
[35] R. Imura, H. Koyanagi, M. Miyamoto, A. Kikukawa, T. Shintani and S. Hosaka, Demonstration of nanometer recording with a scanning probe microscope. Abstracts, Int. Conf. Micro. and Nano. Engineering, Davos, Swizerland, 1994, pp. 52-53.

[36] T.C. Reiley, L.S. Fan and H.J. Mamin. Micromechanical structures for data storage, Abstracts. Int. Conf. Micro-and Nano-Engineering. Davos. Swizerland, 1994. pp. 128-129.

[37] H.J. Mamin, L.S. Fan, S. Hoen and D. Rugar, Tip-based data storage using micromechanical cantilevers. Sensors and Actuators A, $\$ 8$ (1995) 215-219.

[38] Y. Hashimoto, M. Yamamoto and T. Asada, Cameras and display systems, Proc. IEEE. 83 (1995) 1032-1043.

[39] L.E. Tannas, Evolution of flat-panel displays, Proc. IEEE, 82 ( 1994) 499-509.

[40] K. Wemer, U.S. display industry on the edge, IEEE Spectrum, (May) (1995) 62-69.

[41] I. Gorog. Displays for HDTV: direct-view CRT's and projection systems, Proc. IEEE, 82 (1994) 520-536.

[42] J.B. Sarnpsell, The digital micromirror device and its application to projection displays. Tech. Digest. 7th Int. Conf. Solid.State Sensors and Actuators (Transducers '93), Yokohama, Japan, 7-10 June. 1993. pp. 24-27.

[43] H. Kulk, W. Doleschal, A. Gehner, W. Grundke, R. Melchter, J. Paufter, R. Ze! umann and G. Zimmer. Deformable micromirror devices as fase modulating high resolution light valves, Sensors and Actuators A. 52-54 (1996) 536-541.

[44] J. Itoh. K. Tsuburaya and S. Kanemaru. Field emitter arrays for vacuum microelectronics, Tech. Digest, IIth Sensor Symp., Japan. 1992. pp. 143-148.

[45] S.E. Huq, L. Chen and P.D. Prewet1, Sub $20 \mathrm{~nm}$ silicon field emitters produced by electron beam lithography and isotropic plasma etching. Abstracts. Int. Conf. Aicro- and Nano-Engineering. Davos. Swizerland, 1994, pp. 260-261.

[46] I. Brodie and P.R. Schwoebel, Vacuum microelectronic devices, Proc. IEEE, 82 (1994) 1006-1034.

[47] G. Hashiguchi, H. Mimura and H. Fujita, Multi-layered fabrication of microstructures and thin film transistors. Proc. IEEE MEMS Workshop. San Diego, CA. USA, 1996, pp. 49-54.

[48] J. Chen and K.D. Wise, A high-resolution silicon monolithic nozzle array for inkjet printing. Tech. Digest. 8th Int. Conf. Solid.State Sensors and Actuators/Eurosensors IX. Stockholm. Sweden. 1995. Vol. 2. pp. 321-324.

[49] P. Krause, E. Obermeijer and W. Wehl, Backshooter - a new sman micromachined single-chip inkjet printhead. Senors and Actuators A. 52-54 (1996) 405-409.

[50] S. Hirata, Y. Ishii, H. Matoba and T. Inui, An ink-jet head using diaphragm microactuator, Proc. IEEE MEMS Workshop. Sun Diego, CA, USA, 1996, pp. 418-423.

[51] K. Deng and $M$. Mehregany, Outer motor polysilicon wobble micromolors, Proc. IEEE MEMS Workshop, Oiso, Japan, 1994, pp. 269-272.

[52) A.A. Yasseen. S.W. Smith. M. Mehregany and F.L. Merat. Diffracting grating scanners using polysilicon micromotors, Proc. IEEE MEMS Workshop. Amsierdam. Nesherlands, 1995, pp. 175180.

[53] Y. Ohtuka, H. Nishikawa, T. Koumura and T. Hattori, 2-Dimensional optical scanner applying a corsional resonator with 2 degrees of freedom, Proc. IEEE MEMS Workshop. Amsterdam, Netherlands, 1995, pp. 306-309.

[54] T.S.J. Lammerink, M. Elwenspoek and J.H.J. Fluitman, Integrated micro-liquid dosing system, Proc. IEEE MEMS Workshop. Fort Lauderdale, FL, USA. 1993, pp. 254-259.

[55] J.K. Robentson and K.D. Wise, A nested electrostatically actuated microvalve for an integrated microflow controller, Proc. IEEE MEMS Workshop. Oiso. Japan, 1994, pp. 7-12. 
[56] W. Menz, LIGA and related technologies for industrial applications, Tech. Digest. 8th Int. Conf. Solid-State Sensors and Actuators Eurosensors IX. Stockholm, Sweden, 1995. Vol. I. pp. 552-555.

[57] R. Miyake. T.S.J. Lammerink, M. Elwenspoek and Jan H.J. Fluitman, Micro mixer with fast diffusion. Proc. IEEE MEMS Workshop, Fort Lauderdale, FL, USA, 1993, pp. 248-253.

[58] J. Branebjerg. P. Gravesen. J.P. Krog and C.R. Nielsen. Fast mixing by lamination. Proc. IEEE MEMS Workshop, San Diego. CA, USA. 1996, pp. $441-446$.

[59] M.J. Zdeblick, R. Anderson, J. Jankuwski, B. Kline-Schoder, L. Christel, L. Miles and W. Weber, Thermopneumatically actuated microvalves and integrated electro-fluidic circuits. Proc. Actuators 94, Bremen, Germany, 1994, pp. $56-60$.

[60) T.S.J. Lammerink, N.R. Tas, J.W. Berenschot, M.C. Elwenspock and J.H.J. Fluitman, Micromachined hydraulic astable multivibrator, Proc. IEEE MEMS Workshop. Amsterdam. Netherlands. 1995. pp. 13-18.

[61] Y. Ikei, A. Koga. H. Morikawa and Y. Okawa, Fluid driven microactuator with feedback mechanism. Proc. IEEE MEMS Workshop. Fort I suderdale, FL. USA. 1993, pp. 213-218.

[62] M. Elwenspoek. T.S.J. Lammerink, R. Miyake and J.H.J. Fluitman, Towards Integrated micro liquid handling systems. J. Micromech. Microeng., 4 ( 1994 ) 227-245.

[63] M.J.Zdeblick. Brochure, Redwood Microsystems Inc., 959 Hamilton Ave., Menlo Park, CA 94025, USA.

[64] K. Ikuta, K. Hirowatari and T. Ogata. Three dimensional micro integrated filuid systems (MIFS) fabricaled by stereo lithography. Proc. IEEE MEMS Workshop. Oiso. Japan. 1994, pp. 1-6.

[65] R. Furlan and J.N. Zemel, Comparison of wall atachment and jet deflection microfluid amplifiers. Proc. IEEE MEMS Workshop. San Diego, CA. USA. 1996. pp. 372-377.

[66] K. Imanaka, Micro hybrid integrated devices and components: micro photonic devices, SPIE Proc., Vol. 175, 1992. pp. 343-352.

[67] P.P. Deimel. Micromachined devices for optical applications. Tech. Digest, 8th Int. Conf. Solid-Stuse Sensor : and Actuators/Eurosinsors IX. Stuckholm. Sweden, 1995, Vol. 1, pp. 340-343.

[68] L. Lin, S. Let, M.C. Wu and K.S.J. Pister. Micromachined integrated optics for free-space inerconnections, Proc. IEEE MEMS Workshop. Amsterdam, Netherlands, 1995. pp. 77-82.

[69] W. Karthe, R. Göring, A. Brtuer, E.B. Kley, Ch. Wachter, P. Dannberg and T. Poszner, Micro- and integrated optical devices in glasses and polymers for hybrid integration into microsystems. Microsystem Technol. I (1995) 59-67.

[70] G. Vdovin, S. Middelhoek and L. Sarro, Deformable mirror display with continuous reflecting surface micromachined in silicon, Proc. IEEE MEMS Workshop. Amsterdam. Netherlands, 1995, pp. 61-65.

[71] M. Hisanaga, T. Koumura and T. Hattori, Fabrication of 3dimensionally shaped Si diaphragm dynamic focusing mirror, Proc. IEEE MEMS Workshop. Fort Lauderdale, FL, USA, 1993, pp. 303.5.

[72] R. Sawada, O. Ohguchi, K. Mise and M. Tsubamoto, Fabrication of advanced optical micro-encoder chip. Proc. IEEE MEMS Workshop. Oiso. Japan. 1994, pp. 337-342.

[73] R. Sawada, Integrated optical encoder, Tech. Digest. $8 \mathrm{th}$ int. Conf. Solid-State Sensors and Actmators/Eurosensors IX. Stockholm. Sweden, 1995, Vol. I, pp. 281-284.

[74] H. Miyajima, E. Yamamoto, M. Ito, S. Hashimoto, I. Komazaki, S. Shinohara and K. Yanagisawa, Optical micro encoder using surfaceemining laser, Proc. IEEE MEMS Workshop. San Diego. CA. USA. 1996. pp. 412-417.

[75] M. Ikeda, H. Goto, M. Sakata, S. Wakabayashi, K. Imanaka, M. Takeuchi and T. Yada, Two dimensional silicon micromachined optical scanner integrated with photodetector and piezoresistor, Tech. Digest, 8th $/ \mathrm{nt}$. Conf. Solid-State Sensors and Actuators/Eurosensors IX. Stockholm. Sweden, 1995, Vol. 1. pp. 293-296.
[76] D.E. Sene, J.W. Grantham, V.M. Bright and J.H. Comtois, Development and characterization of micro-mechanical gratings for optical modulation, Proc. IEEE MEMS Workshop. San Diego. CA. USA. 1996, pp. 222-227.

[77] Y. Kikuya, M. Hirano, K. Koyabu and F. Ohira, Micro alignmens machine for optical coupling. Proc. IEEE MEMS Wortshop, For Lauderdale, FL, USA. 1993, pp. 36-41.

[78] R. Wechsung. Microstructure components in polymers, first industrial applications, MST News, 14 (1995) 13-19.

[79] L. Paratte and N.F. de Rooij. Electrodeposited clectrostatic wobble motors on silicon for wrist watch applications, Abstr. Late News Papers. 7th Ins. Conf. Solid-Skate Sensors and Actuavors (Transducers '93). Yokohama, Japan, 7-10 Jwne. 1993. pp. 4-5.

[80] G.-A. Racine. C. Beuret, L. Luthier and N.F. de Rooij, Speed control of electric force motors by means of integrated piezoelectric sensors. Proc. IEEE MEMS Wortshop. Ciso, Japian. 1994, pp. 124-129.

[81] P.D. Griffis and S.J. Lipoff, At the croseroads of the iaformation highway: new technology directions in consumer electronics, Proc. IEEE. 82 (1994) 459-464.

[82] D. Anastassiou, Digital television, Proc. IEEE, 82 (1994) 510-519.

[83] J.L. Flaragan, Technologies for multimedia communications, Proc. IEEE, 82 (1994) $590-603$.

[84] J. Hofmann. Nerworking consumet producis in the home, Proc. ICEE. 82 (1994) 615-622.

[85] Y. Kubota, Y. Nishi. K. Shintani. T. Urabe, K. Shimuda and T. Kausumoto, Latest advances in camcorder technolosy, Proc. IEEE, 82 (1994) $537-543$.

[86] H. Narumiya, Micromachine technology (intraluminal diagnostic and therapeutic system), IARP Workshop on Micromachine Technologies and Systems. Tokyo. 1993/Micromachine Summir. Kyoto. Japan, 1995. paper no. 23.

[87] J.A. Adam. Technoloty 1996: merical eiectronics, ItEE Specrnm, (January) (1990) 92-95.

[88] J. de Boer. J. Korf and H Plijter-Groendijk. In vivo monitoriag of lactate and glucose with microdialysis and enzyme reactors in intensive care medicine. Int. J. Artificial Organs, 17 (1994) 16.3170.

[89] H. Hinkers, C. Dumschat, R. Steinkuhl. C. Sondenneijer. K. Cammann and $M$. Knoll, Microdial ysis system for continuous glucose monitoring. Tech. Digess. 8th Inr. Conf. Solid-Stave Sensors and Actuators/Eurosensors IX. Stocktmolm, Sweden. 1995, Vol. 1, pp. 470473.

[90] B. Winter. Development of a miniarurized continuous monitoring system for in vivo applications, AST.News, 13 (1995) 4-5.

[91] J. Drake and H. Jermen, A precision flow restrictor for medical infusion therapy. Tech. Digest, $8 \mathrm{th}$ Int. Conf. Solid-Stale Sensors and Actwators/Eurosensors IX, Stockholm. Sweden, 1995, Vol. I, pp. 373376.

[92] J.A. Adam. Technology comba disabilities, IEEE Spectrum. (Oct.) (1994) 24-26.

[93) D. Haronian and N.C. MacDonald. A microelectromechanics besed artificial cochlea (MEMBAC). Sensors and Actuators A. 52-54 (1996) 288-298.

[94] D. Crawford, Implant works wonders for deaf babies. New Scientist, (23 Sept.) (1995) 11.

[95] W. Affane and T.S. Birch. A miniature electromagnetic middle-ear implant hearing device. Sensors and Actuators A. $46-47$ ( 5995) 584587.

[96] R.P. Ried, E.S. Kim, D.M. Hong and R.S. Mulker, Piezoclectric microphone with on-chip CMOS circuits, J. MEMS, 2 (1993) III120.

[97] P. Bergveld. The merit of using silicon for the development of hearing aid microphones and intracular pressure sensors. Sensors and Actuators B. $41-42$ (1994) 223-229.

[98] P.R. Scheeper, A.G.H. van der Donk, W. Olthuis and P. Bergveld, A review of silicon microphones, Sensors and Actuators A, 4 (1994) I-1I. 
[99] P.E. Lacy. Treating diatetes with transplanted cells, Scicntific American, (July) (1995) 40-46.

[100] M.W. Van Toor, Design and realisation of a manually adjustable, implantable valve for use in a glaucoma filter implant, Designer's Thesis. University of Twente, Enschede, 1995.

[101] K. van Schuylenburgh, E. Peeters, B. Puers, W. Sansens and A. Neetens, Ar: implantable telemetric tonometer for direct intraocular pressure measurements, Abstr., Ist Eur. Conf. Biomed. Eng. Nice. France. 1991.pp. 194-195.

[ 102] V. Spiering. V. Gass, S. Jeanneret, N.F. de Rooij, K.H. Widmer, B. Zurfluh and $E$. Morscher, A system to measure 3-directional relative displacements for a biomedical application, Microsystem Technol., $I$ (1995) 88-92.

[ 103] J.-U. Meyer, H. Beutel, E. Valderrama, E. Cabruja, P. Aebischer, G. Soldani and $P$. Dario, Perforated silicon dices with integrated nerve guidance channels for interfacing peripheral nerves. Proc. IEEE MEMS Workshop. Amsterdam. Netherlands, 1995, pp. 358-361.

[104] E. Valderrama, P. Garrido, E. Cabrujo, P. Heiduschka, A. Harsch and W. Göpel, Microfabrication and characterization of microelectrode arrays for in vivo nerve signal recording. Tech. Digest, 8th Int. Conf. Solid-State Sensors and Actuators/Eurosensors IX, Stockholm. Siveden, 1995, Vol. I. pp. 63-66.

[ 105] T. Akin, K. Najafi and R.M. Bradley. An implantable multichannei digital neural recording system for a micromachined sieve electrode. Tech. Digest. 8th Int. Conf. Solid-State Sensors and Actuatirs' Eurosensors IX. Stockholm. Sweden. 1995. Vol. 1, pp. 51-54.

[106] A.B. Frazier.D.P.O'Brien and M.G. Allen, Two dimensional melallic microelectrode arrays for extracellular stimulation and recording of neurons, Proc. IEEE MEMS Workshop, For Lauderdale, FL, USA. 1993, pp. 195-200.

[107] B. Ziaic, M. Nardin, J. von Arx and K. Najafi. A single channel implantable microstimulator for neuromuscular stimulation (FNS), Proc. 7th Int. Conf. Solsd-State Sensors anci Actuators (Transducers 93). Yokohama, Japan, 7-10 June, 1993, pp. 450-453.

[108] M. Nardin and K. Najafi. A multichannel neuromuscular microstimulator with bi-directional telemetry, Tech. Digest, $8 \mathrm{sh}$ Int. Conf. Solid-Stase Sensors and Actuators/Eurosensors IX. Stockholm. Sweden, 1995. Vol. 1, pp. 59-62.

[109] D. Jackson, B.J. Kane, S. Mnnroe, J. Li, C.W. Scorment, G.T.A. Kuvacs and D.L. Tanalian, A feedback controlled silicon microprube for quantitative mechanical stimulation of nerve and tissue, $J$. Neurosci. Meshods. 60 (1995) 157-163

[110] T. Akin, B. Zjaic and K. Najafi, A modular micromachined highdensity cotinector for implantable biomedical systems, Proc. IEEE MEMS Workshop, San Diego, CA, USA, 1996, pp. 497-502.

[111] Y. Hirata. H. Okuyama and S. Ogino, Piezoelectric composites for micro-ultrasonic transducers realized with decp-etch X-ray lithography, Proc. JEEE MEMS Workshop. Amsterdam, Netherlands. 1995, pp. 191-196.

[112] 3. Maeda, K. Abe, K. Yamamoto, O. Tohyama and H. IN, Active endoscope with SMA (shape memory alloy) coil springs, Proc. IEEE MEMS Workshop, San Diego, CA, ('SA, 1996, pp. 290-295.

[113] C.S. Taylor, P. Cherkas, H. Hampton, J.J. Frantzen, B.O. Shah, W.B. Tiffany, L. Nanis, P. Booker, A. Salahieh and R. Hansen. 'Spatial forming': a three dimensional printing process. Proc. IEEE MEMS Workshop, Amsterdam, Netherlands, 1995, pp. 203-208.

[114] K. Ikuta, T. Kato and S. Nagala, Micro active forceps with optical fiber scope for intra-ocular microsurgery, Proc. IEEE MEMS Workshop. San Diego, CA. USA, 1996, pp. 456-461.

[115] K. Ikuta, M. Nokala and S. Aritomi, Biomedical micro robots driven by miniature cybernetic actuator, Proc. IEEE MEMS Workshop, Oiso. Japan, 1994. pp. 263-268.

[116] A. Abbas, L. Dufour, E. Sarraute and S. Allano, Design of an electromagnetic micromotor for an uftras.jnic echographical system. Proc. Actuator, Bremen, Germuny, 26-28 June, 1996.
[117] U. Wallrabe, J. Mohs, I. Tesari and K. Wulff, Power churacteristics of 3-D operated microturbines for minimally invasive therapy. Proc. IEEE MEMS Workshop, San Diego, CA, USA, 1996, pp. 462-466.

[118] A. Lal and R.M. White, Silicon microfabricated homs for power ultrasonics. Sensors and Actuators A. 52-54 (1996) 542-546.

[119] R. Dizon, H. Han and M.L. Reed, Single-mask processing of micromechanical piercing structures using ion milling. Proc. IEEE MEMS Workshop, Forr Lauderdale, FL, USA, 1993. pp. 48-52.

[120] C. den Besten and P. Bergueld, A new tonometer based on the application of micro-Inechanical sensors, Proc. IEEE MEMS Workshop. Fort Lauderdale. FL, USA. 1993, np. 105-110.

[121] G.C. Klein Lebbink (ed.). Microsystems and agriculture, in Microsystem Technology, Exploring Opportunities, Samson, The Netherlands, 1994. pp. 193-226.

[122] H. Guckel, T. Earles, J. Klein, D. Zook and T. Ohnstein, Electromagnetic linear actuators with inductive position sensing for micro relay, micro valve and precisioning applications, Sensors and Actuators A, 52-54 (1996) 386-391.

[123] R. Legtenberg, Electrostatic actuators fabricated by surface micromachining techniques, Ph.D. Thesis, University of Twente, Enschede. 1996.

[124] M.J. Daneman, N.C. Tien. O. Solgaard, A.P. Pisano, K.Y. Lau and R.S. Muller, Linear nicrovibromotor for positioning optical components, Proc. IEEE MEMS Workshop. Amsierdam. Neinerlands, 1995. pp. 55-60.

[125] T. Akiyama and K. Shono, Controlled stepwise motion in polysilicon microstructures. J. MEMS, 2 (1993) 106-110.

[126] T. Akiyama and $H$. Fujita, A quantitative analysis of scratch drive actuator using buckling motion, Proc. IEEE MEMS Workshop. Amsierdam. Netherlands, 1995, pp. 310-315.

[127] M.J. Lercel, R.C. Tiberio, H.G. Graighead, C.W. Sheen and D. Allara. Electron benin nano fabrication with self-assembled monolayers of alkanethiols and alkylsilanes, Atstracts, Int. Conf. Micro- and NonoEngineering, Davos, Switzerland, 1944, pp. 54-55.

[128] R.J. Jacknıan, J.L. Wilbur and G.M. Whitesides, Pabrication of submicromete- featuics on curved substrates by microcontact printing, Sciens :, 269 (1995) 664-666.

[129] N. Kramer, J. Jorritsma, H. Birk and C. Schönenberger, Nanometer lithography on silicon and hydrogenated amorphous silicon with low energy electrons, Absti acts, Int. Conf. Micro-and Nano-Engineering. Davos, Swizerland, 1994, pp. 24-25.

[130] M.A. Beiley and S S. Wong, Micro-Inachined array probe card, IEEE Elecron Devices Meet., San Francisco, CA, USA. 1992, p.509.

[131] M.J. Riezenman, Technology 1996: test and measurement. IEEE Specirum, (Jan.) (1996) 65-69.

[132] C. Lee, Y. Kim, Y.-G. Choi, Y -H. Cho, K. Lee and B.M. Kwak, High-density silicon microprobe arrays for LCD pixel inspection. Proc. IEEE MEMS Workshop. San Diego, CA. USA. 1996, pp. 428434.

[133] H.H. Langen, M. Masuzawa and M. Fujino. Self-aligning machining and assembly of high aspect ratio microparts into silicon. Proc. IFEE MEMS Workshop. Amsierdam, Netherlands, 1995, pr. 2.10-255.

[134] AUTOMELEC, Company Brochure, Switzerland.

[135] X.-Q. Sun, T. Masuzawa and F. Fujino, Micro ultrasonic machining and self-aligned multilayer machining/assembly technologies for 3D mirromachines, Proc. IEEE MEMS Workshop, San Diego, CA. USA, 1996, pp. 312-317.

[136] H. Miyazake and T. Sato. Fabrication of 3D quantum optical devices by pich-and-place forming. Proc. IEEEMEMS Workshop, San Diego. CA, USA, 1996, pp. 318-324.

(137) E.S. Kolesar and C.S. Dyson, Object imaging with a piezoclectric robotic tactile sensor, J. MEMS, 4 ( 1995 ) 87-96.

[138] H. Misawa. Development of ultra-precision handling technique using a laser manipulation method, Micromachine, 12 (Aug.) (1995) 12.

[139] K.F. Böhringer, B.R. Donald and N.C. MacDonald, Single-crystal silicor actuator arrays for micro manipulation tasks. Pruc. IEEE MEMS Workshop. San Diego, CA. USA, 1996, pp. 7-12. 
[140] Y. Suzuki. Flexible microgripper and its application to micromeasurement of mechanical and thermal properties, Proc. IEEE MEMS Workshop, San Diego. CA. USA. 1996, pp. 406-411.

[141] M. Mitsuishi, K. Kobayashi and B. Kramer, Information transformation-based tele-micro-handling/machine system, Proc. IEEE MEMS Workshop. Oiso, Japan, 1994, pp. 303-308.

[142] H. Guckel, T.R. Christenson and K.J. Skrobis, Deep X-ray lithography, metal plating and assembly as fabrication tools for micromechanics. Tech. Digest. 1/th Sensur Symp. Japan, 1992. pp. $1-6$.

[143] J. Elders, H.V. Jansen, M. Elwenspoek and W. Ehrfeld, DEEMO: a new lechnology for the fabrication of microstructures, Proc. IEEE MEMS Workshop. Amsterdnm. Netherlands, 1995, pp. 238-243.

[144] K. Ikuta and K. Hirowatari, Real three dimensional micro fabrication using stereo lithography and metal moulding. Proc. IEEE MEMS Workshop. Fort Lauderdale, FL USA. 1993, pp. 42-47.

[145] K. Suzumori, A. Koga and R. Haneda, Microfabrication of integrated FMAs using stereo lithography. Proc. IEEE MEMS Workshop. Oiso, Japan, 1994, pp. 136-141.

[146] K. Ikuta, T. Ogata, M. Tsubio and S. Kojima, Development of mass productive micro stereo lithography (mass IH-process), Pror. IEEE MEMS Workshop. San Diego. CA. USA, 1996, pp. 301-306.

[147] K. Takahata, S. Aoki and T. Sato, Fine surface finishing method for 3-dimensional structures. Proc. IEEE MEMS Workshop, San Diego. CA. USA. 1996, pp. 73-78.

[148] J.E. Morris. Electrically conductive adhesives, IEEE Trans. Comp. Pack. Manuf. Technol. Part B. 18 (1995) 282-325.

[149] J.H. Lau (ed.), Flip Chip Technoloxies, McGraw.Hill, New York. 1996.

[150] LETI. Brochure Micro Conneclique, LETI/GRPC-CENG, 17 sue der Martyrs, 38054 Grenoble Cedex, France, 1995.

[151] K. Aschenbrenner, J. Gwiasde, J. eldrings, E. Zakel and H. Reichl, Flip chip attachment using non-conductive adhesives and gold ball Bumps. ISHM Int. J. Microcircuits Electronic Packaging. 18 (1995) 154-161.

[152] D.B. Tuckerman (guest ed.), Multichip modules, Special lssue IEEE Trans. Components, Packaging. Manuf. Technol. Part B: Advanced Packaging, 18 (Nov.) (1595).

[153] M.H. Westbrook, Sensors for automotive applications, in B.E. Jones (ed.), Current Advance in Sensors, IOP Publishing, Bristol, UK, 1987.

[154] C.O. Nwagboso (ed.), Automotive Sensory Systems, Chapman and Hail, Lndon, 1993.

[155] C.O. Nwagboso (ed.! Automotive Sensory Syssems, Chapman and Hall, London. 1993. Ch.8.

[156] C.0. Nwagbuso (ed.). Automotive Sensory Systems, Chapman and Hall, London, 1993, Th.6.

[157] Y. Tanaka, Y. Mochida, S. Suginnto, K. Morya, T. Hasegawa, K. Alsuchi and K. Ohwada, A micromachined vibrating gyroscope. Proc. IEEE MEMS Workshop. Amslerdam. Nstherlands. 1995, pp. 278-281.

[158] J. Bernstein. S. Cho, A.T. King. A. Kourepenis, P. Maciel and M. Weinberg. A micromachined comb-drive tuning fork rating gyroscope. Proc. IEEE MEMS Workshop, For Lauderdale, FL, USA, 1993, pp. 143-143.

[159] A. Singh, M. Mehregany, S.M. Phillips, R.]. Harvey and M. Benjamin, Micrornachined silicon fuel atomizers for gas turbine engines, Proc. IEEE MEMS Workshop. San Liego. CA. USA. 1996. pp. $473-478$.

[160] C.O. Nwagboso (ed.), Automotive Sensory Systems, Chapman and Hall, London, 1993, Ch.9

[161] E.E. Covert. Evolution of the comnerrial airliner, Scientific American. 273 (Sept.) (1995) 82-85.

[162] C. Huang, J. Papp, K. Najafi and H.M. Nagib. A microactuator system for the stidy and contro! of screech in high speed jets. Proc. IEEE MEMS Workshop. San Diego, CA, USA, 1996, pp. 19-24.
[163] Int. Conf. Insegrated MicroNanotechnology for Space Applications. 1995. Houston. TX, USA, abstract booklet.

[164] C.R. Price and K. Grimm, Sprint: the first fight demonstration of the external work system robots, Abstr.. Int. Conf Integrated Microd Nanotechnology for Space Applications, Houston, TX. USA. I995. pp. 43.

[165] V. Spiering. P. Bergveld, M. Elwenspoek and A. van den Berg. A sensor array in a fluidic system for space applications, Froc. Dusch Sensor Conf. Delf. Nesherlands, 20-2I March, 1996.

[166] T.R. Ohnstein. J.D. Zook, J.A. Cox, B.D. Speldrich. T.J. Wagener, H. Guckel, T.R. Christensen, J. Klein, T. Earles and I. Glasow, Tunable IR filters using fiexible metallic microstructures, Proc. IEEE MEMS Workshop. Amsterdam, Netherlands. 1995. pp. 170-174.

[ 167 ] P. Rangsten, L. Smith, L. Rosengren and B. Hök, Electrostatically excited diaphragm driven as a loudspeaker. Sensors and Actwators $A$. 52-54 (1996) 211-215.

[168] T. Idogakj. Micromachine technology (advanced maintenance rechnologies for electric-power plants). IARP Workshop Micromachine Technol. Syst. Tokyo, 1993/Micromachine Summit. Kyoto. Japan. 1995, paper no. 22.

[169] H. Golo, H. Otra, K. Imanaka and T. Yada, Scanning optical sensor for micro mbor, IARP Wortshop Micromachine Technol. Syst., Tokyo 1993/Micromachine Sumumis. Kyoto. Japan. 1995, paper no. 25

[170] Y. Hamasaki and T. Ide, Fabrication of multi-layer eddy current micro sensors for non-destructive inspection of small diameter pipes, Proc. IEEE MEMS Workshop. Amsterdam. Nerherlands. 1995, pp. 232237.

[171] R.J. Reay, C.W. Storment, A. Flannery, S.P. Kounaves and G.T.A. Kovacs. Microfabricared electrochemical analysis system for heavy metal detection. Tech. Digest, 8th Int. Conf. Solid-Stale Sensors and Actwators/Eurosensors/X. Stockholm, Sweden, 1995, Vol. 2, pp. 932935.

[172] M. Plomp. Manipulation with scanning probe microscopy, MESA Internal Report. 1994, 22 pp.

[173] W.M. Arnold and W. Benecke. Levitation. holding and rotation of cells within uraps made by high-frequency fields. Biochim. Biophys. Acta, 1108 (1992) 215-223.

[174] E. Henderson, Imaging of living cells by atomic force microscopy. Surface Sci. $\$ 6$ ( 1994) 39-60.

[175] C.-J. Kim, A.P. Pisano and R.S. Mulker. Silicon processed overtanging microgripper. J. MEMS. I (1992) 31-36.

[176] S.-W. Lee, J.-H. Choi and Y.-K. Kim. Design of a biological cell fusion device. Tech. Digest. Sih Int. Conf. Solid-State Sensors and Acruators/Eurosensors IX. Stockholm. Sweden, 1995, Vol. 1, pp. 377380.

[177] J.P. Brody. Th.D Osborn, F.K. Forster and P. Yager, A planar microfabricased fluid filter, Sen sors and Actuators A, 52-54 (1996) 704-708.

[178] J.-U. Meyer. Micropattemed biocompatible materials with applications for cell cultivation, J. Micromech. Microeng.. 5 (1995) 172-174.

[ 179] D. Sobek, A.M. Young, M.L. Gray and S. Senturia, A microfabricated flow chamber for optical measurements in fluids, Proc. IEEE MEMS Workshop. Fort Lauderdale, FL USA, 1993, pp. 219-224.

[180] W.T. Muller, D.L. Klein. T. Lee, J. Clarke, P.L. McEuen and P.G. Schultz. A strakegy for the chemical synthesis of nanostructures, Science, 268 (1995) 272.

[181] A. van den Berg and P. Bergveld (eds.). Micro Tolal analysis Systems. Kluwer, Dordrech, 1994.

[182] G. Mills, F. Walsh and I. White, Electrochemical gas sensing devices. Chem. Technol. Europe, (Jul./Aug.) (1995) 20-24.

[183] S. Svanberg. Chemical sensing with lasir spectroscopy, Tech. Digest. 8th Int. Conf. Solid-State Sensors and Actmators/Eurosensors IX. Srockholm. Sweden, 1995, Vol. 1, pp. 35-38.

[184] R. Hintsche. M. Paeschke, A. Uhlig. C. Kruse. F. Dittrich, M.T. Phan and S. Howitz. Different couplings of electrochemical chip sensors with actuators in microanalytical fluidic systems, Tech. Digest. 8th 
Ins. Conf. Solid-State Sensors and Actuators/Eurosensors IX, Stockholm, Sweden, 1995, Vol. 1.pp. 772-774.

[185] W. Wei. J. Lin, Q. He, G. Wu, J. Wang and M. Fen, Liquid core optical fibre spectrophotometry for trace element analysis, Tech. Digest, 8 ih Int. Conf. Solid-State Sensors and Actuators/Eurosensors IX. Stockholm. Sweden. 1995, Vol. 2. pp. 811-813.

[186] A. van den Berg. T.S.J. Lammerink, V. Spiering and W. Olthuis, Modular concept for miniature chemical systems, DechemaMonographien, Microreactors, 1995.

[187] R.R. Reston and E.S. Kolesar, Silicon-micromachined gas chromatography system used to separate and detect ammonia and nitrogen dicxide Part I: design, fabrication and integration of the gas chromarography system. J. MEMS, 3 (1994) 134-146.

[188] E.S. Kolesar and R.R. Reston, Silicon-micromachined gas chromatography system used to separate and detect ammonia and nitrogen dioxide Part II: evaluation, analysis and theoretical modeling of the gas chromatography system. J. MEMS, 3 (1994) 147-154.

[189] G. Ohcvirk, E. Verpoorte, A. Manz and A.M. Widmer, Integration of a micro liquid chromatograph onto a silicon chip, Tech. Digest. 8 th Int. Conf. Solid-State Sensors and Actuators/Eurosensors IX, Stockholm, Sweden, 1995, Vol. I, pp. 756-759.

[190] D.E. Raymond. A. Manz and H.M. Widmer, Continuous sample preparation using free-flow electrophoresis on a silicon microstructure, Tech. Digest, $8 \mathrm{th}$ Int. Conf. Solid-State Sensors and Actuators/EurosensorsIX. Stockholm. Sweden, 1995. Vol. 1, pp. 760763.

[191] O. Ohman. Electrophoresis in plastic channels, Micro Structure Bulletin. 2 (1995) 2-3.

[192] T. Laurell, J. Drost and L. Rosengren, Silicon wafer integrated enzyme reactors, Biosensors Bioelectron., 10 (1995) 289-299.

[193] M.A. Northrup, C. Gonzalez, D. Hadley, R.F. Hills, P. Landre, S. Lehew, R. Saiki, J.J. Sninsky, R. Watson and R. Watson, Jr., A MEMS based miniature DNA analysis system, Tech. Digest, 8 th $/ m t$. Conf. Solid-State Sensors and Actuators/Eurosensors IX, Stockholm. Sweden, 1995, Vol. 1. pp. 764-767.

[194] M. Albin, E. Picozza, E. Winn-Deen and T. Woudenberg. The role/ issues for microtechnology for genetic analysis. Pacifichem 95 , Honolulu, HI, USA, 1995, Abstr. 233.

[195] M.J. Heller, An active microelectronic device for multiplex DNA hybridization analysis, Pacifichem 95. Honolulu, HI, USA. 1995, Abstr. 235.

[196] D.B. Wallace, High throughput array for fluid microdispensing in DNA diagnostics. Post Workshop Microfabrication, 2nd Ann. Biochip Array Technol. Conf.. Marina del Rey, 19 Murch. 1996.

[197] R. Vuilleumier and K. Krayczek. Variable entrance slit system for precision spectrophotometers, Proc. IEEE MFMS Workshop. Amsterdam, Netherlands, 1995, pp. 181-185.

[198] H.C. Nathanson, I. Liberman and C. Freidhoff, Novel functionality using micro-gaseous devices. Proc. IEEE MEMS Workshop. Amsterdam. Netherlands, 1995, pp. 72-76.

[199] G.M. Shedd and P.E. Ru'ssell, The scanning tunneling microscope as a tool for nanofabrication, Nenoteihnology, $l$ (1990) 67-80.

[200] A. Ruf, M. Abraham, M. Lacher, K. Mayr and Th. Zetnerer, A miniaturized Fabry Perot AFM sensor, Yech. Digest, 8th Int. Conf. Solid-State Sensors and Actuators/Eurosensors IX. Stockholm. Sweden, 1995. Vol. 1. pp. 660-663.

[201] U. Harmann, T. Gödsenhenrich and C. Heiden, Mzgnetic force microscopy: cument status and future trends. J. Magn. Mot., 10I (1991) 263-270.

[202] N.F. Van Hulst, M.H.P. Moers and B. Bulger, Near-field Gptical microscopy in transmission and reflection modes in combination with force microscopy, J. Microsc.. $17 /$ ( 1993) 95-105.

[203] T. Itoh, T. Ohashi and T. Suga. Piezoelectric cantilever amray for multiprobe scanning force micros spy. Proc. IEEE MEMS Workshop, San Diego, CA. USA. 1996. pp. 451-455.

[204] V.W.S. Chan. All-optical networks, Scientific American, 273 (Sept.) (1995) 56-59.
[205] L.A. Field. D.L. Burriesci, P.R. Robrish and R.C. Ruby. Micromachined $1 \times 2$ fiber switch. Tech. Digest, $8 \mathrm{th} / \mathrm{mt}$. Conf. SolidState Sensors and Actuators/Eurosensors IX, Stockholm. Sweden. 1995. Vol. I. pp. 344-347.

[206] B. Culshaw. Fibre optic sensor: integration with micromachined devices, Sensor and Actuators A, 46-47 (1995) 463-469.

[207] J.H.J. Fluitman, Sensors as systerns/sensors in systerns, Proc. Int. Symp. Sensors in the 21st Century, Tokyo, Japan, 1992, pp. 81-88.

[208] W. Olthuis. J. Luo and P. Bergueld. Characterization of proteins by means of their buffer capacity, measured with an ISFET-based coulometric sensor-actuator system, Biosensors Bioeleciron., 9 (1994) 743-751.

[209] W. Olthuis and P. Bergveld, Performance of the coulometric sensoractuator device improved by MicroTAS, Proc. MicroTAS 94 Workshop, Enschede. Nesherlands, 1994, pp. 273-277.

[210] O. Brand, H. Baltes and U. Baldenweg. Ultrasound-transducer using membrane resonators realized with bipolar IC technology, Proc. IEEE MEMS Workshop. Oiso, Japan, 1994, pp. 33-38.

[211] F. Paoletti, M.-A. Gretillat and N.F. de Rooij. A silicon micromachined vibrating gyroscope with piezoresistive detection and electromagnetic excitation, Proc. IEEE MEMS Workshop, San Diego, CA. USA, 1996. pp. 162-167.

[212] T. Niino. S. Egawa, H. Kimura and T. Higuchi, Electrostatic artificial muscle: compact high-power tinear actuators with multiple-layer structures, Proc. IEEE MEMS Workshop, Oiso, Japan, 1994, pp. 130135.

[213] M.W. Hamberg, C. Neagu, d.G.E. Gardeniers, D.J. Ijntema and M. Elwenspoek. An electrochemical micro actuator. Proc. IEEE MEMS Workshop, Amsterdam, Netherlands. 1995, pp. 106-110.

[214] A.D. Johnson and E.J. Shahoian, Recent progress in thin film shape memory microactuators, Proc. IEEE MEMS Workshop, Amsterdam. Netherlands, 1995. pp. 216-220.

[215] M. Shikida and K. Sato, Characteristics of an electrostatically-driven gas valve under high-pressure conditions, Proc. IEEE MEMS Workshop. Oiso, Japan. 1994, pp. 235-240.

[216] M. Shikida, K. Sato and T. Hurada. Fabrication of an electrostatic microactuator with an S-shaped film, Tech. Digest, Bith Int. Conf. Solid-State Sensors and Actwators/Eurosensors IX. Stockholm. Sweden, 1995. Vol. 1, pp. 426-429.

[217] H. Tilmans, Micro-mechanical sensors using encapsulated built-in resonant strain gauges, Ph.D. Thesis, University of Twente. Enschede, 1993.

[218] P. Enoksson, G. Stemme and E. Stemme, Vibration mode investigation of a resonant silicon tube structure for use as a fluid density sensor, Proc. IEEE MEMS Workshop. Amsterdam, Nesherlands. 1995, pp. 113-138.

[219] K.E. Petersen, H.V. Allell and J.W. Knutti, Micro-miniature force sensitive switch, Int. Patent Application WO 85,03383 (1985).

[220] D.V. Allen. Silicon based micromechanical swilches for industrial applications, Proc. IEEE Micro Robots and Tileoperators Workshop. Hyannis, MD, USA, 9-II Nov., 1987.

[221] M. Sakata, An electrostatic microactuator for electromechanical relay, Proc. IEEE MEMS Workshop. Sals Lake City, UT, USA, 1989, pp. 149-151.

[222] S. Roy and M. Mehregany, Fabrication of electrostatic nickel micrnrelays by nickel surface micromachining. Proc. IEEE MEMS Workshop. Amsterdam, Nelizerlands, 1995, pp. 353-35\%.

[223] B. Rogge. J. Schulz. J. Mohr. A. Thommes and W. Menz, Fully batch fabricated magnetic micractuators using a two-layers LIGA process, Tech. Digest, 8th Int. Conf. Solid-Staie Sensors and Actuutors, Eurosensors IX. Siockholm. Sweden, 1995. Vol. 1. pp. 320-323.

[224] M.-A. Gretillat, P. Thiebaud, N.F. de Rooij and C. Linder. Electrostatic polysilicon microrelays integrated with MOSFETS, Proc. IEEE MEMS Wurkshop. Oiso. Jałan, 1994, pp. 97-101.

[225] H. Hosaka, H. Kuwano and K. Yanagisawa, Electromagnetic microrelays: concepts and fundamental characteristics, Proc. IEEE MEMS Workshop. Fort Lauderdale, FL, USA, 1993, pp. 12-17. 
[226] J. Vollmer, H. Hein, U. Köhler and W. Menz, Microminiarure fluidic beam elements as electro-pneumatic converters, Proc. Actwators 94 . Bremen, Germ. ny. 1994, pp. 38-41.

(227) W. Horsthuis, i olid state optical switches, AKZO NOBEL Newslerser, (Oct.) (1995)

[228] T. Lisec. S. : ¿brschelmann, H.J. Quenzer, B. Wagner and W. Benecke. Therit ally driven microvalve with buckli $: 8$ behaviour for pneumatic app : ations, Proc. IEEE MEMS Workshop, Oiso, Japan. 1994, pp. 13-!

[229] B. Wagner, H.. Quenzer, S. Horschelmann, T. Lisec and M. Juerss, Bistable micro /alve with pneumatically coupled nembranes, Proc. IEEE MEMS W,orhushop, San Diego, CA, USA, 19\%0, pp. 384-388.

[230] N. Ëturtinen. Micro electro thermo fluidic (METF) liquid microprocessol. Proc. IEEE MEMS Workshop, San Diego, CA, USA. 1996, pp. 395- : 99.

[231] R.E. Pelrine, J.: Eckerle and S. Chiba, Review of artificial muscle approaches, Prcc. 3rd Int. Symp. Micro Machine and Human Science, Nagoya 1992/Micromachine Summit, Kyoto, Japan, 1995, paper 28.

[232] S. Kawamura, K. Minani and M. Esashi, Fundamental research of distributed electrostatic micro actuator, Tech. Digest, IIth Sensor Symp., Japan, 1992, pp. 27-30.

[233] K. Minami, S. Kawamura and M. Esashi, Fabrication of distributed electrostatic micro actuator (DEMA), J. MEMS, 2 (1993) 121-127.

[234] T. Niino, S. Egawa and T. Higuchi, High-power and high-efficiency electrostatic actuator, Proc. IEEE MEMS Workshop, Fort Lauderdale. FL, USA, 1993, pp. 236-241.

[235] M. Yamaguchi, S. Kawamura, K. Minami and M. Esashi, Distributed electrostatic micro actuator, Proc. IEEE MEMS Workshop. Fort Lauderdale, FL, USA, 1993, pp. 18-23.

(236) S.M. Bobbio, M.D. Kellam, B.W. Dudley, S. Goodwin-Johansson, S.K. Jones, J.D. Jacobson. F.M. Tranjan and D. Dubois, Integrated force arrays, Proc. IEEE MEMS Workshop. Fort Lauderdale, FL. USA, 1993, pp. 149-154.

[237] T. Moriizumi, Biomimetic sensing systems with arrayed nonspecific sensors, Tech. Digest, 8th int. Conf. Solid-State Sensors and Actwators/Eurosensors IX, Stockholm, Sweden, 1995, Vol. 1. pp. 3942.

[238] S. Konishi and $\boldsymbol{H}$. Fujita. A conveyance system using air flow based on the concept of distributed motion systems, Tech. Digest. $7 \mathrm{~h} \mathrm{~h} \mathrm{nt}$. Conf. Solid-State Sensors and Actuators (Transducers '93), Yokohama, Japan, 7-10 June, 1993, pp. 28-31.

[239] S. Konishi and H. Fujita. System design for cooperative control of arrayed microactuators, Proc. IEEE MEMS Workshop. Amsterdum. Necherlands, 1995, pp. 322-327.

[240] C. Liu, T. Tsao, Y.-C. Tai, W. Liu, P. Will and C.-M. Ho. A micromachined permalloy magnetic actuator amay for micro robotics assembly sysiems, Tech. Digest, 8 ih Int. Conf. Solid-State Sensors and Actuators/Eurosensors IX, Stockholm, Sweden, 1995, Vol. I, pp. 328-331.

[241] K.F. Böhringer, B.R. Donald, R. Mikzilovich and N.C. MacDonald. A theory of manipulation and control for microfabricated actuntor arrays, Proc. IEEE MEMS Workshop. Oiso, Jupan, 1994. pp. 102107.

[242] M. Ataka, A. Omodaka and H. Fujita, A biomimetic micro motion system, a ciliary motion system, Tech. Digest, 7th Imt. Conf. SolidState Sensors and Actuaters (Transducers '93). Yokohama. Japan. 7-10 June. 1993. pp. 38-41.

[243] M.S. Moesner and T. Higuchi, Devices for particle handling by an AC-electric field, Proc. IEEE MEMS Workshop. Amsterdan: N. therlands. 1995. pp. 66-71.

[244] P.A.F.M. Goemas, Microsystems and energy, in Microsystem Technology, Exploring Opportunities, Samsom. The Netheriands. 1994, pp. 50-64.

[245] R. Puers, Linking sensors with telemetry: impact on the system design, Sensurs and Actuators A. S2-54 (1996) 169-174.
[246] T. Sakakibara, H. lzu, T. Kura, W. Shinohara, H. Iwata, S. Kiyam and S. Tsuda, High-vohtage photovohaic micro-devices fabricaled by a new laser processing. Proc. IEEE MEMS Workshop, Amstendam, Netherlands. 1995, pp. 282-287

[247] J.B. Loe, Z. Chen. M.G. Allen. A. Rohutgi and R. Arya, A high roltage solar cell array as an electrostatic MEMS power sipply. Proc. IEEE MEMS Workshop. Oiso, Japan. 1994. pp. 331-336.

[248] J.B. Bates, G.R. Gruzalski and C.F. Luck. Rechargeable solid stase lithium microbatteries. Proc. IEEE MEMS Workshop. Fort Lauderdale, FL. USA, 1993. pp. 82-86.

[249] M.J. Riezenmen. The search for better butteries, IEEE Spectrum. (May) (1995) 51-56.

[250] R. Zengerle, S. Kluge, M. Richer and A. Richter, A bidirectional silicon micropurmp. Proc. IEEE MEMS Workshop, Amsterdain. Netherlands, 1995, pp. 19-24.

[251] 8. Buistgens. W. Bacher. W. Menz and W.K. Schomburg. Micropunp manufactured by thermoplastic molding, Proc. IEEE MEMS Wortshop, Oiso, Japan, 1994, pp. 18-21.

[252] R. Rapp. P. Bley, W. Menz and W.K. Schomburg. Micropurnp fabricated with the LIGA-process, Proc. IEEE MEMS Workshop. Fort Lauderdale, FL, USA, 1993. pp. 123

[253] H. Fujita. Recent progress of microactuators and micromotors, Microsystem Technol. I (1995) 93-97.

[254] W.S.M. Trimmer and K.J. Gabriel, Design considerations for a practical electrostatic micromotor. Sensors and Actuators. $1 /$ (1987) 189-206.

[255] U. Wallmabe, P. Bley, B. Krever. W. Menz and J. Mohr, Design rules and test of electrostatic micromotors made by the LIGA proceass, $J$. Micromech. Microeng. 4 (1994) 40-45.

[256] H. Guckel, T.R. Christenson, K.J. Skrobis, T.S. Jung, J. Kkein, K.V. Hartojo and I. Widjaja. A first functional current excived ptanar rotational micromotor. Proc. IEEE MEMS Wortshop, Fort Lauderdale, FL. USA, 1993, pp. 7-11.

[257] C.H. Ahn, YJ. Kim and M.G. Allen, A planar variable reluctance magnetic micromotor with fully integrated stator and wrapped coils, Proc. IEEE MEMS Workshop. Fort Lauderdale, SL. USA. 1993, pp. $1-6$.

[258] K. Matzuzaki, T. Matsua and Y. Mikurya, Comparison of electrostic and electromagnetic motors based on fabrication and performance criteria, Proc. Sth Int. Symp. Micro Machine and Human Science. Nagoya 1995/Micromachine Summit, Tokyo, Japan, 1995, paper no. 10.

[259] K. Nakamura, H. Ogura, S. Maeda, U. Sangaws. S. Aoki and T. Salo, Evaluation of the micro wobble motor fabricaled by concentric buildup process, Proc. IEEE MEMS Workshop. Amsterdam, Netherlands. 1995. pp. 374-379.

[260] R. Legtenberg. E. Berenschot, J. van Baar, T. Lammerink and M. Elwenspock. An electrostimic lower stakor axial gap wobble motor: design and fabrication. Tech. Digest. 8th Int. Conf. Solid-State Sensors and Actuators/Eurosensors IX. Stockholm. Sweden. 1995, Vol. 2, pp. 404-407.

[261] L. Parante, H. Lorens, R. Luthier, R. Clavel and N.F. de Rooij. Miniature gem reduction unit driven by a silicon electrostatic wobble motor, Proc. IEEE MEMS Workshop. Oiso, Japan, 1994, pp. I19123.

[262] W. Trimmer and R. Jebens. An operational harmonic electrostatic motor, Proc. IEEE MEMS Workshop. Salt Lake City, UT, USA, 1989. pp. 269-272.

[263] K. Deng, M. Mehregany and A.S. Dewa, A simple fabrication process for side-drive micromotors, Tech. Digest, 7th Int. Conf. Solid.Stave Sensors and Actuators (Transducers '93), Yokohama, Japan, 7-10 June, 1993. pp. 756-759.

[264] T. Furuhata, T. Hirano, L.H. Lane, R.E. Fontane, L.S. Fan and H. Fujita, Outer rotor surface micromachined wobble micromotor, Proc. IEEE MEMS Workshop. Fort Lauderdale. FL, USA, 1993, pp. 161166. 
[265] R. Legtenberg. E. Berenschot, M. Elwenspoek and J.H.J. Fiuitman, Electrostatic microactuators with integrated gear linkages for mechanical power transmission. Proc. IEEE MEMS Workshop. San Diego, CA, USA. 1996, pp. 204-209.

[266] E.J. Garcia and J. Sniegowski, Surface micromachined microengine as the driver for micromechanical gears, Tech. Digest, $8 \mathrm{th}$ Int. Conf. Solid-State Sensors and Actuators/Eurosensors IX. Stockholm, Sweden, 1995, Vol. 1, pp. 365-368; Seisors and Actuators A. 48 (1995) 203-214.

[267] Y. Yamagata, T. Higuchi, N. Nakamura and S. Hamamura, A micro mobile mechanism using thermal expansion and its theoretical analysis: a comparison with impact drive mechanism using piezcr!: ctric elements, Proc. IEEE MEMS Workshop, Oiso. Japan. 1994. pp. 142-147.

[268] K.I. Arai, W. Sugawara and T. Honda, Magnetic small flying machines, Tech. Digest. 8th Int. Conf. Solid-Stale Sensors and Actuators/Eurosen.sors IX. Stockholm. Sweden, 1995, Vol. 1, pp. 316319.

[269] 1. Shimoyama, Y. Kubo, T. Kaneda and H. Miura. Simple microflight mechanism on silicon wafer. Proc. IEEE MEMS Workshop. Oiso. Japan. 1994, pp. 148-152.
[270] C. Liu, T. Tşao, Y Taj, T. Leu, C. Ho, W. Tang and D. Miu, Out-ofplane permalloy magnetic actuators for delta wing control, Proc. IEEE MEMS Workshop. Amsierdam, Netherlands, 1995, pp. 7-12.

[271] T. Fukuda, A. Kawamoto, F. Arai and H. Matsuur, Stesring mechanism and swimming experiment on micro mobile robot in water, Proc. IEEE MEMS Workshop. Amsterdam. Netherlands. 1995. pp. $300-305$.

[272] H.M.B. Bird. Approaches to electronic miniaturization, IEEE irans. Comp., Packaging Manuf. Technol., 18A. (1995) 274-278.

[273] C.H. Stappet and R.J. Rosner, Integrated circuit yield management and yield analysis: developnent and implementation, IEEE Trans. Semicond. Manufact. 8 (1995) 95-102.

[274] E.A. Sack, Consumer electronics: an important driver of integrated circuit technology, Proc. IEEE, 82 (1994) 465-468.

[275] K.F. Schoch and H.E. Saunders, Conducting polymers, IEEE Spectrum, (June) (1992) S2-55.

[276] A. Dodabalapur, L. Torsi and H.E. Katz, Organic transistors: twodimensional transport and improved electrical characteristics. Science, 258 (1995) 270-271. 